\title{
CMENTARZ W STRUKTURZE PRZESTRZENNEJ MIASTA
}

\begin{abstract}
Zarys treści: Umieranie nie mieści się we współczesnej globalnej kulturze pop gloryfikującej młodość i witalność. Jeśli dodać do tego katolickie sacrum-tabu śmierci okaże się, że dzisiaj nie ma miejsca na cmentarze. Celem artykułu jest pokazanie, że nie da się ich jednak wyprzeć, że są częścią każdej cywilizacji i mają lokalizację w przestrzeni i krajobrazie. Ważnym spostrzeżeniem jest to, że znaczenie i miejsce cmentarzy zmieniało się tak, jak zmieniała się kultura. Posłużono się przykładem Łodzi.
\end{abstract}

Słowa kluczowe: cmentarze, lokalizacja cmentarzy, Łódź, łódzkie cmentarze.

\section{Wprowadzenie}

Cmentarze to immanentna część prawie każdej cywilizacji, prawie każdej społeczności. Chowanie zmarłych jest elementem bycia człowiekiem, choć z pewnością istnieją tu różnice kulturowe, a obyczajowość zmieniała się w czasie. Pochówek nie zawsze oznaczał, czy oznacza grzebanie. Zawsze jednak ludzie tworzą specjalną przestrzeń pamięci i kontaktu ze zmarłymi. J. Kolbuszewski (1996) nazywa cmentarze ,tekstami kultury”, w których odbija się ludzki stosunek do śmierci i życia. Pisze:

Cmentarz jest przestrzennie określonym zbiorem grobów - znaków o jednostkowych, indywidualnych i niepowtarzalnych znaczeniach, których suma - nie będąca wynikiem arytmetycznego dodawania - tworzy znaczenie całości (Kolbuszewski 1996).

Cmentarze bardziej niż kościoły mają wymiar społeczny i kulturowy. Są w równym stopniu dostępne dla wszystkich, również dla tych, którzy nie identyfikują się ze wspólnotą wyznaniową ${ }^{1}$.

\footnotetext{
${ }^{1}$ Szczególnie w miastach, coraz częstsze są pochówki osób niewierzących na wyznaniowych cmentarzach. Wynika to także z norm prawa świeckiego (por. Ustawa o cmentarzach i chowaniu zmartych z dnia 31 stycznia 1959 roku, Dz.U., 1959, nr 11, poz. 62 z późn. zm.).
} 
Gdy spojrzeć na zachowanie katolików okazuje się, że inaczej niż w przypadku wspólnot działających przy parafiach, będących egzemplifikacją społecznego oddziaływania Kościoła (oczywiście nie jedyną), nie ma tu (na cmentarzu) mowy o jakiejkolwiek hermetyczności. Wykluczenia są niezwykle rzadkie, a odmowa pochówku na ogół bywa źle przyjmowana przez lokalną grupę wiernych. Cmentarze miejskie, podobnie jak duże wspólnoty parafialne sprawiają, że odwiedzający je ludzie i znajdujące się tam groby pozostają anonimowi. Tylko niektóre nekropolie i mogiły są identyfikowane i stają się częścią nazwanej tożsamości - miasta, regionu, kraju. Tak jest z pewnością z cmentarzami powązkowskim, łyczakowskim i rakowickim. Tożsamość łodzian próbuje się budować odwołując do Cmentarza Starego, położonego przy ul. Ogrodowej. W wymiarze indywidualnym cmentarz i groby stają się miejscem duchowego spotkania z nieżyjącymi przodkami. To zaś buduje tożsamość każdego człowieka, daje szansę na określenie, skąd się jest oraz do jakiej grupy i do jakiej przestrzeni się należy - daje szansę na własną historię.

Celem artykułu jest zaprezentowanie ewolucji lokalizacji cmentarzy w mieście i pokazanie ich dzisiejszej lokalizacji na przykładzie Łodzi. Praca ma charakter kompilacyjny.

\section{Cmentarze. Geneza i lokalizacja}

Dzisiejszy wygląd i lokalizacja miejskich cmentarzy to efekt wielosetletniej, jeżeli nie dłuższej, ewolucji stosunku ludzi do śmierci i zmarłych. Pojęciem pierwotnym jest tu z pewnością grób. Pojawia się on w kulturach, których członkowie zaczynają zadawać sobie pytanie o to, co dzieje się z człowiekiem po śmierci. Dzięki odkryciom archeologicznym wiemy, że w grobach grzebali swoich zmarłych już neandertalczycy ${ }^{2}$. W neolicie na obszarze dzisiejszej Europy zachodniej (głównie we Francji) pojawiły się monumentalne menhiry ${ }^{3}$, na Bałkanach groby ciałopalne. Najprawdopodobniej w X wieku p.n.e. powstały pierwsze cmentarze lokowane poza osiedlami, zwyczaj upowszechnił się 500 lat później wraz z rozwojem miast. Wcześniej grzebano zmarłych w obrębie osad, a nawet w domach (Górniak 2003).

Od starożytności cmentarze były uważane za obszar sacrum, w związku z tym znajdowały się pod specjalną ochroną prawną. Miejsca pochówków były lokowane poza granicami miast, do czego obligowała litera prawa. Prawo Dwunastu Tablic oraz kodeks Teodozjusza nakazywały grzebać zmarłych poza granicami osad. Początkowo cmentarze podlegały jurysdykcji cesarzy. Później, za sprawą reformy wprowadzonej przez papieża Dionizego w III wieku n.e., zaczęły

\footnotetext{
${ }^{2}$ Odkrycia w jaskini Szanidar.

${ }^{3}$ Menhiry to pojedyncze obeliski. Używa się także określenia megality, rozszerzając je również na bardziej złożone konstrukcje.
} 
podlegać ustawodawstwu wyznaniowemu. W 313 roku Konstantyn Wielki ogłosił wolność wyznania w Cesarstwie ${ }^{4}$. Na kanwie tej decyzji rozpoczęła się budowa i adaptacja budynków na cele kościelne, w ślad za czym pojawił się zwyczaj przenoszenia relikwii męczenników do kościołów oraz grzebania wiernych w świątynnych murach. Na tamten okres datuje się również praktykę chowania zmarłych w sąsiedztwie ciał męczenników, ponieważ istniało przekonanie, że zachowa to zmarłych w pamięci potomnych (Dziobek-Romański 1998). Poza murami miast powstawały podmiejskie sanktuaria, które z upływem czasu zaczęły przekształcać się w bazyliki i skupiać ruch pielgrzymkowy. Świątynie przyciągające pielgrzymów stawały się pożądanym miejscem dla spoczynku zmarłych i tworzyły centrum nowego cmentarza. Wraz z rozwojem jednostek osadniczych włączano je w ich granice. Zdarzało się tak mimo wciąż obowiązującego zakazu grzebania w granicach miast. Ograniczenie zostało zniesione dopiero przez cesarza Leona VI w Cesarstwie Wschodnim, w Zachodnim odwołał je Synod w 563 roku w Bradze. Zezwolono wówczas na pochówki tuż obok murów kościelnych, jednakże tylko od zewnętrznej strony (Ariès 1989).

Cmentarze żydowskie natomiast, we wczesnym średniowieczu, były najczęściej tworzone poza miastem. W okresie kiedy chrześcijaństwo docierało na ziemie Słowian, na cmentarzach rozpoczęto wznoszenie świątyń po to, aby zamaskować ich pogański charakter. Na ziemiach polskich pierwotne cmentarze ${ }^{5}$ zostały przekształcone w chrześcijańskie nekropolie, stopniowo przenoszone do osad, głównie miejskich (Tanaś 2008; Długozima 2011).

W 1059 roku odbył się Sobór Rzymski, który zezwolił na lokowanie grobów przy kościołach. Zadekretowano wydzielanie terenu o szerokości 60 kroków (jeśli pochówek miał być urządzany w pobliżu świątyni) lub 30 kroków w przypadku, kiedy miejsce spoczynku zmarłego miało być urządzone wokół kaplicy. Synod w Tuluzie w 1093 roku nakazał tworzenie dwóch rodzajów cmentarzysk. Jedne były przeznaczone dla duchowieństwa i szlachetnie urodzonych, natomiast drugie dla pozostałych wiernych. Istotne jest to, że średniowieczne cmentarze nie były jedynie miejscem pochówku zmarłych, pełniły one również rolę miejsca publicznego. Pozareligijne aktywności na cmentarzach były krytykowane przez Kościół, co jest widoczne w notacjach Synodów lokalnego kościoła, np. w Polsce. Akty prawa kościelnego ukazujące się od XIII do XVIII wieku miały za zadanie chronić miejsca wiecznego spoczynku przed profanacją. Biskupi za ich sprawą zobowiązywali proboszczów do pielęgnowania odpowiedniego

\footnotetext{
${ }^{4}$ Edykt Mediolański.

${ }^{5}$ Pomimo tego, że wyraz „cmentarz” w polszczyźnie występuje już od początków chrześcijaństwa, został on zapisany dopiero na początku XV wieku jako smentarz, gdyż kojarzony był ze smutkiem, smuceniem się, smętkiem. W rzeczywistości wyraz „cmentarz” wywodzi się z łacińskiego słowa coemeterium. W grece mamy natomiast koimeterion - miejsce grzebania zmarłych, miejsce spoczynku.
} 
porządku w miejscach spoczynku (Tabela 1). Pokazują one nie tylko to, jak cmentarz powinien wyglądać, by stać się miejscem sacrum, ale przede wszystkim, jak był wtedy traktowany przez wiernych.

Tabela 1. Zapisy porządkowe synodów od XIII do XVIII wieku dotyczące cmentarzy

\begin{tabular}{|c|c|c|}
\hline Rok & Synod & Ustalenia \\
\hline $\begin{array}{l}1233 \\
1248\end{array}$ & Prowincjonalny & $\begin{array}{l}\text { Cmentarze ogrodzone, urządzone i poświęcone przez biskupów } \\
\text { mają prawa imminitatis eccl. (schronienia), stąd gwałciciele ich } \\
\text { podlegają klątwie i jako wyklęci ogłaszani być powinni }\end{array}$ \\
\hline 1512 & Gnieźnieński & $\begin{array}{l}\text { Ogrodzenie cmentarza murem, drewnianym parkanem lub oko- } \\
\text { pane rowem, sadzenie drzew chroniących kościół przed poża- } \\
\text { rami }\end{array}$ \\
\hline 1568 & Włocławski & $\begin{array}{l}\text { Obowiązkiem plebanów utrzymanie porządku na cmentarzach, } \\
\text { zakaz paszenia bydła i wpuszczania nań trzody }\end{array}$ \\
\hline 1583 & Chełmiński & $\begin{array}{l}\text { W bramie cmentarza umieszczenie kraty żelaznej lub drewnia- } \\
\text { nej broniącej wejścia zwierzętom; tylko patronom przysługuje } \\
\text { grób murowany w kościele, inni powinni uzyskać zgodę bisku- } \\
\text { pa, sadzenie drzew chroniących kościół przed pożarami }\end{array}$ \\
\hline 1610 & Warmiński & $\begin{array}{l}\text { Zakaz rozwieszania pościeli, wystawiania i mycia naczyń ku- } \\
\text { chennych, browarnych, przesiewania lub suszenia zboża oraz } \\
\text { innych prac pod utratą rzeczy na cmentarzach wyłożonych; } \\
\text { kostnice powinny mieć gęste kraty, aby zwierzęta nie wcho- } \\
\text { dziły, posiadać napis, wewnątrz krzyż zawieszony lub namalo- } \\
\text { wany; groby w kościele powinny być min. } 2 \text { łokcie od ołtarza } \\
\text { oddalone }\end{array}$ \\
\hline 1636 & Żmudzki & $\begin{array}{l}\text { Sprzeciw wobec pochówków w polu, postulat grzebania zmar- } \\
\text { łych na łonie Kościoła }\end{array}$ \\
\hline 1641 & Łucki & $\begin{array}{l}\text { Sprzeciw wobec pochówków w polu, postulat grzebania zmar- } \\
\text { łych na łonie Kościoła }\end{array}$ \\
\hline 1641 & Włocławski & $\begin{array}{l}\text { Odprawianie pogrzebów przed i po zachodzie słońca zabronio- } \\
\text { ne, zalecenie, aby zmarli nawet najubożsi byli z przyzwoitością } \\
\text { chowani przez kapłanów }\end{array}$ \\
\hline 1641 & Przemyski & $\begin{array}{l}\text { Obowiązek grzebania biednych zmarłych kosztem plebana lub } \\
\text { kościelnej skarbony }\end{array}$ \\
\hline 1643 & Płocki & $\begin{array}{l}\text { Nakaz nauczania ludu, aby przechodząc przez cmentarz „mod- } \\
\text { lił się za umarlych tam spoczywających” }\end{array}$ \\
\hline 1711 & Krakowski & $\begin{array}{l}\text { Grób murowany w kościele przysługiwał patronom (kollato- } \\
\text { rom) }\end{array}$ \\
\hline 1738 & Poznański & $\begin{array}{l}\text { Porządek i staranie o całość ogrodzenia należy do obowiązków } \\
\text { plebana }\end{array}$ \\
\hline
\end{tabular}




\begin{tabular}{|c|c|c|}
\hline Rok & Synod & Ustalenia \\
\hline 1744 & Wileński & $\begin{array}{l}\text { Za pochowanie w polu lub w lesie winny ma zakaz wstępu do } \\
\text { kościoła przez trzy miesiące }\end{array}$ \\
\hline 1745 & Chełmski & $\begin{array}{l}\text { Kara za odmówienie lub zwłóczenie pogrzebu dla nieopłaco- } \\
\text { nych pieniędzy }\end{array}$ \\
\hline 1762 & Kijowski & $\begin{array}{l}\text { Nałożenie na biskupów obowiązku poświęcenia cmentarza } \\
\text { przy kościele lub innego miejsca przeznaczonego na grzebanie } \\
\text { zmarłych i odłączenie go od świeckiego użytku, zakaz rozwie- } \\
\text { szania sukien świeckich i bielizny na terenie cmentarza; teren } \\
\text { cmentarza nie powinien służyć za drogę publiczną, nie powi- } \\
\text { nien być wykorzystywany do sprzedaży, targów lub jarmarków; } \\
\text { fundusz na reparację i ogrodzenie cmentarza dają parafianie, } \\
\text { oczyszczenie i zachowanie porządku należy do obowiązków } \\
\text { plebana; aby cmentarz mógł korzystać z prawa azylu musi nań } \\
\text { znajdować się krzyż wielki oraz naczynie z wodą święconą, je- } \\
\text { śli groby w kościele są położone bliżej niż } 2 \text { łokcie od ołtarza to } \\
\text { w ciągu } 6 \text { miesięcy usunięte; nakaz chowania zmarłych dzieci } \\
\text { w oddzielnym grobie }\end{array}$ \\
\hline
\end{tabular}

Źródło: A. Długozima (2011).

Odpowiedzialna za cmentarze była Ecclesia - ściślej np. probostwo. Co więcej, cmentarze podlegały prawu patronatu. W miastach ten przywilej miała przeważnie rada miejska. Natomiast na wsiach nad nekropoliami czuwała szlachta. W XIII wieku pojawił się zwyczaj, który mówił, że tylko biskup może poświęcić cmentarz.

Pogląd mówiący o tym, że miejsce chowania zmarłych powinno znajdować się poza granicami miasta, w znacznej odległości od świątyni, pojawił się w Odrodzeniu. Teren na jakim mieli być grzebani zmarli ściśle określało prawo kanoniczne. Wymogiem było ogrodzenie i krzyż, których obecność miała uświęcać przestrzeń i pozwolić na włączenie cmentarza do obiektów sacrum. Kolejnym elementem był nakaz segregacji pochówków: groby zmarłych dzieci miały znajdować się w zupełnie innym miejscu niż dorosłych osób świeckich. Wydany przez Papieża Pawła V w XVII wieku tzw. Rytuał Rzymski ${ }^{6}$, pozwolił na uporządkowanie przestrzeni sakralnej. Dotyczył on przede wszystkim sposobu chowania ciała w grobie. Szczegółowo mówi o tym akt z 1614 roku, którego zapisy wyraźnie wskazują, że zwłoki powinny być składane w takim kierunku, w jakim wierzący znajdowali się w kościele, wschodnio-zachodni, z głową na wschód, zaś duchowni z głową na zachód (Dziobek-Romański 1998).

\footnotetext{
${ }^{6}$ Rituale Romanum, księga obrzędowa Kościoła katolickiego.
} 
W XVIII wieku cmentarze stały się przedmiotem zainteresowania władz świeckich. W 1763 roku w Paryżu z inicjatywy Zgromadzenia Narodowego odbyła się kontrola cmentarzy i kościołów pod względem sanitarnym. Przepytano wówczas komisarzy i rady kościelne i ostatecznie 12 marca 1765 roku przyjęto uchwałę o przeniesieniu cmentarzy poza granice miasta. Decyzja podyktowana była złą oceną warunków sanitarnych miejsc grzebalnych. Francuski parlament wydał ustalenie, które jasno mówiło, że wszystkie miejsca pochówku zmarłych i przykościelne dziecińce znajdujące się w miastach mają zostać zamknięte. Teren po ich likwidacji przez co najmniej 5 lat nie mógł być użytkowany. W dokumencie pojawił się również zapis, który mówił, że powierzchnia cmentarzy ma być proporcjonalna do liczby parafian, dla których miejsce to ma być przeznaczone. Każdy obszar pochówku zmarłych miał być ogrodzony kamiennym murem o wysokości 9 stóp, centralne miejsce miała zajmować kaplica, a cmentarze miały być wyposażone w specjalne zaplecze, m.in.: dom przedpogrzebowy, zaś napisy na nagrobkach mogły znajdować się tylko na cmentarnym murze. Cmentarz miał być tylko miejscem pochówku - brak pomników i zieleni. Wynikało to z przeświadczenia, że drzewa będą zaburzać cyrkulację powietrza (Ariès 1989). Co ciekawe, regulacje francuskie opublikowano także w Polsce i innych krajach europejskich, a nawet w Stanach Zjednoczonych ${ }^{7}$ (Kolbuszewski 1996).

Wiek XIX okazał się być przełomowy, jeśli chodzi o administrowanie cmentarzami. Upowszechniły się wtedy trzy wzorce: zarządzanie przez władze religijne, zarządzanie przez państwo lub miasto oraz zarząd prywatny.

Nadal trwały także dyskusje na temat lokalizacji cmentarzy. Za osiągnięcie uznać można On the laying out, planning and managing of cemeteries and on the improvement of churchyards Johna Claudiusa Loudona z 1843 roku. Dzieło to, jak się później okazało, miało ogromny wpływ na kompozycję angielskich cmentarzy, ze względu na szereg wytycznych lokalizacyjnych i projektowych. Te pierwsze określały, że teren ma być o ekspozycji północnej, o statusie umożliwiającym lokalizację cmentarza na planie prostym lub regularnym, gleba ma być sucha do głębokości 6,1 lub 9,1 metra, podłoże nie może być skaliste, a odległość od miasta jest uzależniona od ekspozycji, gleby i źródeł pozyskiwania wody pitnej. Wytyczne projektowe określały m.in.: ogrodzenie, którego wysokość i użyty materiał miały być zależne od charakteru miejsca, w którym cmentarz był lokowany. Do miejsca pochówku miała prowadzić co najmniej jedna główna brama i jedna główna droga (o szerokości od 3,7 $\mathrm{m}$ do $6,1 \mathrm{~m}$ ). Plan zakładał również alejki, dróżki prowadzące do grobów, kaplice, szatę roślinną (Loudon 1843 za: Długozima 2011) - por. Ryc. 1 .

${ }^{7}$ Nowojorska Rada Zdrowia w 1806 roku powołała komisję, która miała czuwać nad raportem w sprawie zachowania koniecznych środków dla zapewnienia ochrony zdrowia mieszkańców, uwzględniającym sytuację w miejscach grzebalnych (Walker 1839 za: Długozima 2011). 

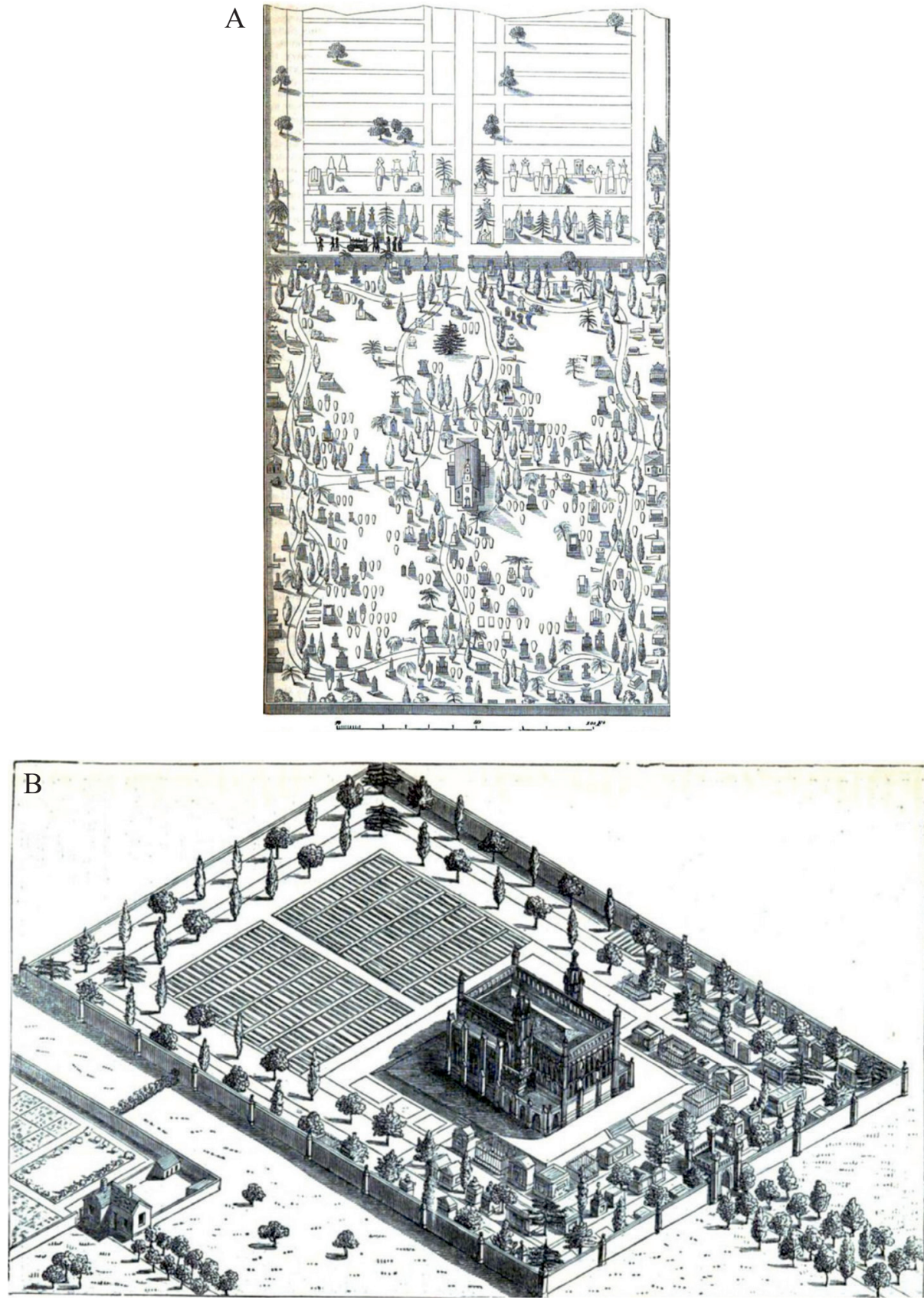

Ryc. 1. Rysunki zamieszczone w pracy Loudona: (A) - tradycyjny cmentarz wiejski; (B) - projekt cmentarza dla wiejskiej parafii według przyjętych kryteriów Źródło: J.C. Loudon (1843). 
W tym okresie zaczęly ukazywać się kolejne świeckie regulacje dotyczące lokalizacji i organizacji cmentarzy. Wśród nich wymienić można: amerykański Rural Cemetery Act z 1847 roku, kanadyjski The Cemeteries Cause Act, z tego samego roku, brytyjskie The Burial Acts.

W konsekwencji w Stanach Zjednoczonych rozpoczęła się komercjalizacja usług pogrzebowych i cmentarzy - w każdym hrabstwie przedsiębiorcy mogli posiadać $1 \mathrm{~km}^{2}$ ziemi przeznaczonej pod pochówki, a cmentarze wyniesiono na tereny pozamiejskie.

W Kanadzie zobowiązano właścicieli cmentarzy do opracowania planów obszarów w takiej skali, aby możliwe było jak najdokładniejsze przedstawienie pól grobowych. Wymuszono także numerację grobów korespondującą z księgami zmarłych i wykazem właścicieli danych pól grobowych.

W Wielkiej Brytanii w 1857 roku utworzony został angielski narodowy system cmentarzy publicznych. Izby pogrzebowe powołane przez parafie miały odpowiadać za tworzenie i urządzanie cmentarzy, ustalać opłaty za sprzedaż i utrzymanie pól grobowych. Kolejny akt, z 1894 roku, odpowiedzialnymi za cmentarze ustanowił lokalne władze (Długozima 2011).

Organizacja cmentarzy pozamiejskich przypominała tę z czasów rzymskich. Najbardziej okazałe pomniki powstawały w pobliżu murów. Najubożsi byli chowani w centralnych częściach nekropolii, w zbiorowych mogiłach oznaczonych jedynie krzyżem. Budowano także kolumbaria, przenosząc wzory grobów z kościołów.

Istotnym elementem przestrzeni grzebalnych była $\mathrm{i}$ jest zieleń. Do dzisiaj wysokie drzewa są czytelnym znakiem cmentarzy w krajobrazie polskich wsi. Drzewa były zresztą sadzone w takich miejscach już w kulturach starożytnych. Ich cykl życiowy, sezonowe obumieranie i odradzanie się, dawało nadzieję. Wertykalizm formy stanowił nawiązanie do wyobrażonej axis mundi. Dzięki tej osi połączyć się mogły światy żywych i umarłych. Po Chrystusie w procesjach żałobnych zaczęto nosić zamiast drzewa krzyż - nowy symbol łączności z sacrum (Kolbuszewski 1996). Jeszcze później drzewa zaczęły wyznaczać granice, strzec tajemnicy świętości. Gdy cmentarze przeniesione zostały poza mury kościelne, zaczęto je traktować jako element ozdobny i tło budujące nastrój do przeżyć duchowych (Sobczak 2003).

Od wieku XVIII funkcjonują cmentarze wyznaniowe i komunalne (świeckie). Jednocześnie zmieniały się poglądy na śmierć i żałobę, a co za tym idzie na funkcje cmentarzy. Kiedyś położone z dala od skupisk ludzkich, włączane były w obręb rozrastających się miast. Ludzie coraz częściej chcieli odwiedzać groby swoich bliskich. Wraz z rodzącym się nacjonalizmem, nekropolie zaczęły odgrywać ważną rolę narodowotwórczą. Szczególnie istotne były w tym procesie cmentarze wojenne. W końcu miejsca wiecznego spoczynku stały się obiektami turystycznymi i ważnymi terenami zieleni w miastach (Ryc. 2) - por. S. Tanaś (2008). 

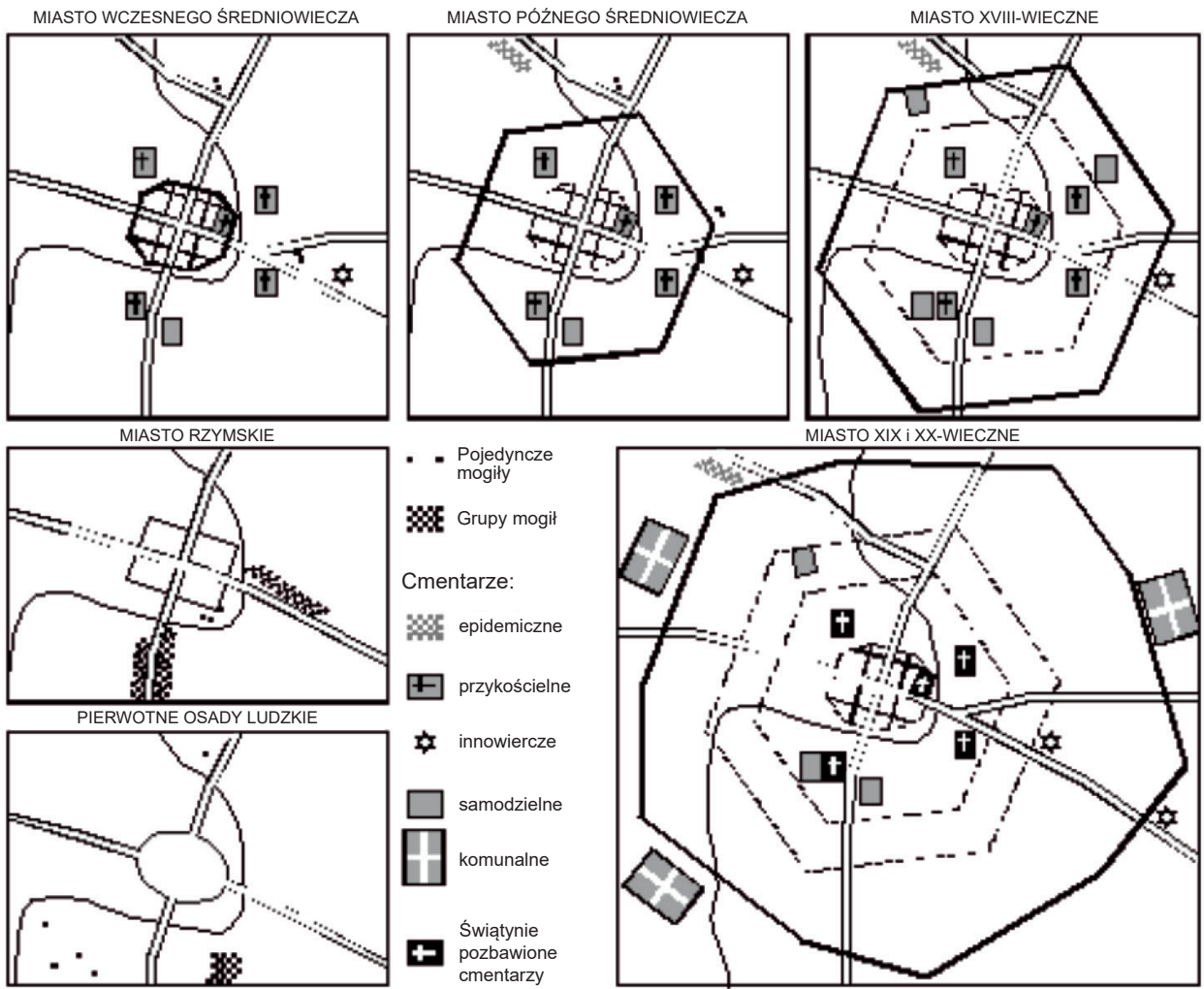

Ryc. 2. Zmiany lokalizacji cmentarzy i ich funkcji

Źródło: oprac. A. Wosiak na podstawie S. Tanaś (2008) za: E. Klima (2011).

\section{Geneza i lokalizowanie cmentarzy w Polsce}

W Polsce pierwszą parafialną nekropolię pozamiejskąa ${ }^{8}$ założyli Księża Misjonarze z Warszawy w 1781 roku. Drugim warszawskim cmentarzem były otwarte w 1791 roku Powązki. Początkowo rozwiązanie takie przyjęto źle - do tego czasu poza terenami miejskimi grzebano jedynie osoby wykluczone - samobójców, skazańców etc. Działania te zbiegły się z orędziem Stanisława Lubomirskiego Marszałka Wielkiego Koronnego, który w 1770 roku pisał do władz kościelnych „aby ogólnie wszelkie cmentarze od dalszego pogrzebania zmarłych wolne zostały, a natychmiast inne miejsca od miast tutejszych dalsze, na wolnym powietrzu, ku obrządkowi temu pobożnemu zdatne, na spoczynek zmarłych wybrane i wyznaczone były" (Kolbuszewski 1996: 182).

\footnotetext{
${ }^{8}$ Dzisiaj to zbieg ulic: Marszałkowskiej, Nowogrodzkiej, Emilii Plater i Wspólnej.
} 
$\mathrm{Na}$ wszystkich dawnych polskich ziemiach od początku lat 90. XVIII wieku miało miejsce zjawisko delokalizowania cmentarzy - prowadzone przez Komisję Policji Obojga Narodów. Wydano wówczas dokument Uniwersat do Miast Wolnych Względem cmentarzy i szlachtuzów, który zakazywał grzebania zmarłych w kościołach oraz nakazywał lokowanie większych cmentarzy extra muros. Skierowany był on do wszystkich grup wyznaniowych, które na jego realizację miały kilka miesięcy. Jak się później okazało, czas był zbyt krótki, w związku z czym dokument nie był skuteczny. Koniecznym było wydanie nowego przepisu. W 1793 roku pojawił się tekst Urządzenie względem ciał zmartych, którego autorem był Kazimierz Nałęcz Raczyński Marszałek Nadworny Koronny.

W Galicji pierwsze rozporządzenia wydane zostały w 1784 roku. Zgodnie z nimi groby i cmentarze kościelne, znajdujące się w obrębie osady, miały zostać zamknięte, a w stosownym oddaleniu miały powstać nowe nekropolie (Holly 2007). O odległości cmentarzy od budynków mieszkalnych decydowały władze administracyjne na podstawie decyzji rzeczoznawców. Kolejny dokument nakazywał usunięcie przykościelnych cmentarzy parafialnych oraz szpitali z obszaru miejscowości. Wydano zakaz o grzebaniu zmarłych w kościołach i na przykościelnych cmentarzach, ograniczono prawo stawiania nagrobków wydając decyzję o ich lokalizacji jedynie przy cmentarnym murze. Określone zostały ścisłe zasady, do których stosowano się określając odległość miejsca pochówku od zabudowy jednostki osadniczej:

- oddalenie było zależne od powierzchni cmentarza,

- teren miał być lokalizowany na północ lub północny wschód, zwłaszcza gdy był otwarty na działanie wiatrów w każdym kierunku,

- teren miał być zabezpieczony przed następstwami powodzi, zagłębień wody deszczowej i roztapiającego śniegu,

- teren był możliwy o rozszerzenie na kolejną parcelę,

- uwzględniony został kierunek biegu źródeł.

Warunkiem pozwolenia biskupa na poświęcenie nowego cmentarza było ogrodzenie go murem lub drewnianym płotem $\mathrm{z}$ bramą wjazdową oraz ustawienie wysokiego krzyża (Dziobek-Romański 1998).

Regulacje obowiązujące w Galicji określały także wytyczne w sprawie organizacji samej przestrzeni grzebalnej. Poza obligatoryjnymi elementami kompozycji (krzyżem i ogrodzeniem) na terenie cmentarza miała znajdować się trupiarnia służąca do czasowego przechowywania zwłok. Powinna być ona wyposażona w piece, po to, by uniknąć zamarznięcia pozornie zmarłych. Kwestie konstrukcyjne obiektów były ściśle określone: drzwi wejściowe miały być cały czas zamknięte, jednak zamek zrobiony tak, aby możliwe było łatwe otworzenie ich od wewnątrz.

Na terenie zaboru pruskiego w 1773 roku Fryderyk II wydał decyzję o przeniesieniu cmentarzy poza miasta. W 1802 roku Departament Finansów Prowincji 
Południowych Prus wydał zezwolenie na pochówek zakonników w grobach klasztornych, jednocześnie zakazując pochówków osób bez zezwolenia biskupa diecezjalnego. Do użytku zostały dopuszczone jedynie szczelnie zamykane groby, zniesiono zwyczaj chowania zmarłych w gołej ziemi. W zaborze rosyjskim, do którego stopniowo były włączane obszary wschodniej Polski, swoiste miejsce zajmowała Warszawa i jej cmentarze. 1783 roku powstał pierwszy cmentarz poza murami miasta, który obsługiwał mieszkańców Warszawy. Był to wspomniany wcześniej założony przez księży Misjonarzy cmentarz świętokrzyski (Dziobek-Romański 1998).

W 1846 roku wszystkie przepisy dotyczące nekropolii i obchodzenia się z ciałami zmarłych zostały zebrane i wydane w postaci ustawy $O$ grzebaniu ciat zmarłych. Ustawa wprowadziła pojęcia grobów „stałych” z nagrobkami oraz „czasowych”. Artykuł 126 odnosił się do form nagrobków trwałych. Wykorzystywanymi materiałami mogły być kamień i żelazo. Nagrobki z tych tworzyw mogły być stawiane na grobach trwale zakupionych, na mogiłach ziemnych mogły stać nagrobki nietrwałe, np. drewniane krzyże. Kształt i napisy nie mogły być niemoralne i miały być pisane w języku polskim. Akt stanowił również o elementach kompozycji. Każdy cmentarz powinien być otoczony ogrodzeniem murowanym, kamiennym lub drewnianym o minimalnej wysokości 7 stóp z bramą. Każdy nagrobek miał zostać oznaczony numerem. Zaplanowano obsadzenie cmentarzy drzewami i krzewami z wykluczeniem drzew owocowych. Ustawa była rewolucyjna, ponieważ jako pierwsza ściśle określiła kryteria lokalizacji nekropolii - cmentarz odległy od miejsc zamieszkałych przynajmniej 800 metrów, położony w nieco spadzistym miejscu, otwarty od wietrznej strony, na terenach oddzielonych od miasta laskiem, pagórkiem lub wodą bieżącą (Dziobek-Romański 1998).

Przepisy prawne w poszczególnych zaborach uchyliła dopiero Ustawa z dnia 17 marca 1932 roku o chowaniu zmarlych i stwierdzeniu przyczyny zgonu. Tę natomiast zmieniono obowiązującą do dzisiaj Ustawa z 31 stycznia 1959 roku o cmentarzach $i$ chowaniu zmarlych.

\section{Współczesne regulacje prawne dotyczące lokalizacji cmentarzy}

W Polskim prawodawstwie kwestie pochówku regulują następujące akty prawne:

- Ustawa z dnia 31 stycznia 1959 roku o cmentarzach i chowaniu zmarlych,

- Rozporzadzenie Ministra Gospodarki Komunalnej z dnia 25 sierpnia 1959 r. $w$ sprawie określenia, jakie tereny pod względem sanitarnym sa odpowiednie na cmentarze ${ }^{10}$,

\footnotetext{
${ }^{9}$ Dz.U., 1959, nr 11, poz. 62 z późn. zm.

${ }^{10}$ Dz.U., 1995, nr 52, poz. 315 z późn. zm.
} 
- Rozporzadzenie Ministra Infrastruktury z dnia 7 marca 2008 roku w sprawie wymagań, jakie musza spetniać cmentarze, groby i inne miejsca pochówku zwłok i szczątków ${ }^{11}$,

- Ustawa z dnia 28 marca 1933 roku o grobach i cmentarzach wojennych ${ }^{12}$.

Na terenie Rzeczpospolitej Polskiej obowiązuje Ustawa o cmentarzach $i$ chowaniu zmarlych, niezależnie czy miejsca pochówku były utworzone przed jej wejściem w życie czy też nie. Artykuł 3 jasno określa, że cmentarze zakłada się i rozszerza na terenach wyznaczonych w oparciu o plany zagospodarowania przestrzennego, a w przypadku ich braku o wytyczne do takich planów. Cmentarze komunalne zakłada się na terenie każdego miasta, gromady i osiedla, w pewnych przypadkach jeden cmentarz może być przeznaczony dla dwóch lub więcej gromad bądź osiedli.

W artykule 5. czytamy:

Cmentarze powinny znajdować się na ogrodzonym terenie, który spełnia odpowiednie wymogi sanitarne. Każdy cmentarz powinien być wyposażony w dom przedpogrzebowy lub kostnicę, które pełnią funkcje:

- składowania ciał zmarłych do czasu ich pochowania,

- są miejscem wykonywania oględzin zwłok do celów lekarskich, sanitarnych i milicyjnych,

- służą do innych czynności związanych z grzebaniem zwłok.

Istotne wydaje się omówienie jednego $\mathrm{z}$ wymogów utworzenia cmentarza, czyli planu miejscowego. Określono, że dla każdego terenu przeznaczonego pod miejsce pochówku, winien być sporządzony plan zagospodarowania terenu zatwierdzony przez organ państwowy nadzoru budowlanego. Ten dokument jest kluczowym przy urządzaniu i dalej funkcjonowaniu cmentarza. Plan powinien składać się z części opisowej i uwzględniać jego powierzchnię, położenie i granice oraz części graficznej z rysunkiem w takiej skali, aby możliwe było łatwe odczytanie zapisów. Rysunek powinien być skonstruowany w sposób jasny i czytelny z wyraźnie zaznaczoną granicą obszaru i liniami rozgraniczającymi tereny o różnym przeznaczeniu, uzupełniony w legendę z elementami oznaczeń.

Miejscowy plan zagospodarowania przestrzennego (MPZP) zawiera informacje dotyczące np. wejścia i wjazdu na cmentarz, położenia kaplicy i domu pogrzebowego wraz z ich powierzchnią i strukturą budowlaną, wysokości zabudowy techniczno-gospodarczej (nie większej niż 1 kondygnacja), wysokości ogrodzenia (minimum 1,5 m). W MPZP ustala się także drogi dojazdowe, lokalizację i powierzchnię parkingów, zalesienie (jeśli istnieje) oraz określa nachylenie terenu (jeśli istnieje).

Teren cmentarny nie może być ponownie włączony do użytku przed upływem 40 lat od chwili ostatniego pochówku. Po upływie tego czasu przeznaczenie terenu

\footnotetext{
${ }^{11}$ Dz.U., 2008, nr 48, poz. 284.

${ }^{12}$ Dz.U., nr 39, poz. 311.
} 
na inne cele jest możliwe, niedopuszczalne jest jednak uszkodzenie pamiątek o wartości historycznej, archeologicznej lub artystycznej. Pamiątki te mogą być przeniesione na inne, odpowiednie miejsca za zgodą właściwego organu administracji.

Ustawa określa także postępowanie z indywidualnymi grobami i zasady dotyczące traktowania osób zmarłych. Mówi, że grób nie może być użyty ponownie przed upływem 20 lat. Po takim czasie może nastąpić kolejny pochówek. Istnieje możliwość pogrzebania jako zwłoki lub poddania kremacji. W przypadku chowania bez spopielania, zwłoki mogą być złożone w grobie murowanym, ziemnych katakumbach bądź przez zatopienie w morzu. Ciało poddane kremacji może być dodatkowo przechowywane w kolumbariach.

Utrzymanie cmentarzy należy do wójtów, burmistrzów lub prezydentów albo przedstawicieli związków wyznaniowych. Cmentarze projektuje się i utrzymuje jako tereny o założeniu parkowym.

Lokalizacja cmentarzy powinna wykluczać możliwość ich szkodliwego oddziaływania na otoczenie, przede wszystkim pod względem sanitarnym. Wyspecjalizowane organy (ministrowie) zajmujące się ochroną zdrowia i ochroną środowiska powinny ustalić szerokość pasów izolujących teren cmentarny od innych terenów, a w szczególności terenów mieszkaniowych, odległość cmentarza od źródeł ujęcia wody oraz wymagania co do poziomu wód gruntowych na terenach przeznaczonych pod cmentarze. Jeżeli to możliwe, nowe cmentarze powinny być lokowane na obrzeżach miast.

Przed ostatnią nowelizacją Ustawy o cmentarzach, minimalną odległość od zabudowań mieszkalnych ustalono na $150 \mathrm{~m}(50 \mathrm{~m}$, jeżeli działa sieć wodociągowa). Odległość od ujęć wody o charakterze zbiorników służących jako źródło zaopatrzenia lokalnych ujęć zaś na nie mniej niż $500 \mathrm{~m}$. W miarę możliwości cmentarze powinny być lokowane na wzniesieniach, poza terenami zalewowymi, o poziomie wód gruntowych nie wyższym niż $2,5 \mathrm{~m}$, tam gdzie wiatry wieją od zabudowań, nie w przeciwną stronę (Sobczak, Gołda-Sobczak 2018).

Cmentarze winny być ogrodzone trwałym parkanem, nie niższym niż $1,5 \mathrm{~m}$. Przewiduje się także wyposażenie tych obiektów w zieleń o charakterze izolacyjnym i dekoracyjnym, w szczególności trawniki, żywopłoty, krzewy i drzewa, w drogi i ciągi piesze lub pieszo-jezdne, place i miejsca postojowe, miejsca przeznaczone na gromadzenie odpadów, punkty czerpalne wody i ogólnodostępne ustępy, dom pogrzebowy lub kostnicę, w szczególnych przypadkach kaplicę i zaplecze administracyjne. Do każdego cmentarza należy zapewnić dojście i dojazd drogami utwardzonymi.

Minister infrastruktury dopuszcza kilka form grobów - ziemne, murowane, rodzinne, katakumby (pomieszczenie z niszami w ścianie, przeznaczone do pochówku zwłok) i kolumbaria (budowla z niszami przeznaczonymi do składania urn). Zakłada się, że przejścia między poszczególnymi mogiłami będą miały minimum $0,5 \mathrm{~m}$, a ustawione nagrobki nie będą wykraczały poza obrys grobu. 
Polskie prawodawstwo wyróżnia trzy typy cmentarzy: komunalne, wyznaniowe oraz wojenne i wojskowe. Cmentarze wyznaniowe, jak sama nazwa wskazuje, charakteryzują się tym, że ich podstawowym przeznaczeniem jest chowanie zwłok osób zmarłych należących do danego wyznania oraz sprawowanie obrzędów religijnych. Zarówno na terenie cmentarza wyznaniowego, jak i komunalnego obowiązują miejscowe regulaminy. To właśnie one ustalają ogólne zasady funkcjonowania cmentarzy od godzin otwarcia i zamknięcia, przez zakres usług cmentarnych, zasady utrzymywania porządku na cmentarzu, nakazy i zakazy obowiązujących zachowan, prace konserwatorów, odbywanie się pogrzebów po czysto estetyczne - zagospodarowanie i wygląd grobów, ustawienie nagrobków, pomników i nasadzeń.

Jeśli chodzi o cmentarze wojenne i wojskowe, do grobów zaliczanych do wojennych należą:

- groby poległych w walkach o niepodległość i zjednoczenie Państwa Polskiego,

- groby wojskowych, zmarłych w wyniku działań wojennych, bez względu na narodowość,

- groby sióstr miłosierdzia i innych osób, które w trakcie wykonywania swoich czynności poległy w trakcie działań wojennych,

- groby osób internowanych i jeńców,

- groby uchodźców z 1915 roku,

- groby wojskowych i cywilnych, bez względu na narodowość, które straciły swoje życie po 1 września 1939 roku,

- groby ofiar niemieckich i sowieckich obozów,

- groby osób, które straciły życie na skutek walk w okresie od 1944 do 1956 r.

Cmentarze wojenne są własnością Skarbu Państwa, który nabywa ziemię w drodze umowy bądź na zasadach określonych w przepisach o wywłaszczeniu ziemi na potrzeby urządzeń użyteczności publicznej.

Zgodnie z obowiązującymi przepisami, nowe cmentarze powinny być lokowane poza zabudowaniami, na terenach przeznaczonych pod zieleń publiczną i z uwzględnieniem dobrego dostępu do sieci komunikacyjnej. Pierwszym etapem prac nad budową nowego cmentarza jest zbadanie, na podstawie planu sytuacyjnego w skali 1:500, środowiska przyrodniczego - gruntów do głębokości pierwszego poziomu wody gruntowej, z określeniem rodzaju, zawilgotnienia, struktury, stopnia kwasowości. Na podstawie tych badań tworzy się opis techniczny i kolejno wykonuje się pomiar spływu wód powierzchniowych, głębokość wód gruntowych oraz kierunek ich spadku. Badaniom poddaje się również roślinność. Na plan należy nanieść wszystkie zabudowania, studnie i ujęcia wody znajdujące się w promieniu $150 \mathrm{~m}$. Przyjmuje się, że teren cmentarza powinien być położony na wzniesieniu, po to, aby uniknąć zalań i podtopień, a najbliższe ujęcie wody pitnej musi znajdować się w odległości od granicy minimum $500 \mathrm{~m}$. 
Kwestię zarządzania cmentarzem jako zabytkiem reguluje w Polsce Ustawa $z$ dnia 23 lipca 2003 roku o ochronie zabytków i opiece nad nimi ${ }^{13}$. Do grupy najbardziej zakorzenionych w polskiej kulturze i jednocześnie zabytkowych cmentarzy należą cmentarze: Rakowiecki i Podgórski w Krakowie, Stary Cmentarz przy Ogrodowej w Łodzi, Stary Cmentarz na Powązkach i Grabiszyński we Wrocławiu. Wspomniana wyżej ustawa określa sposób opieki jaką należy sprawować nad cmentarzami oraz zasady ich konserwacji. Stanowi ona, że każda osoba, która wyraża własną i nieprzymuszoną wolę i działa na rzecz zachowania miejsc bogatych kulturowo, może sprawować nad nimi opiekę, zaś konserwacją mogą zajmować się jedynie profesjonaliści.

Osobnym zbiorem dokumentów jest prawo poszczególnych wyznań. W przypadku Kościoła katolickiego, Konkordat pozostawia inicjatywę zakładania cmentarzy władzom kościelnym, przy zachowaniu konieczności uzgodnień szczegółowych z odpowiednimi władzami świeckimi. Nigdzie nie definiuje się pojęcia „cmentarz”. Prawo określa jednak konieczność i zasady ich tworzenia. Kluczowe jest pobłogosławienie całego terenu, kwater lub pojedynczych grobów (Kan. 1240). Tylko ono sprawia, że miejsce staje się święte - wynika to także z treści Kanonu 1205. Dopuszcza się tworzenie cmentarzy parafialnych, zakonnych oraz należących do osób prawnych (np. bractw lub stowarzyszeń kościelnych) i rodzin. Prawo kościelne kanonizuje także szczegółowe przepisy prawa świeckiego dotyczące pochówków i cmentarzy (Kalinowski 2001). Najważniejsza w tym zakresie jest Ustawa o cmentarzach $i$ chowaniu zmarlych $z$ dnia 31 stycznia 1959 roku ${ }^{14}$.

\section{Cmentarze Lodzi}

Lokalizacja, wygląd i rozwój łódzkich cmentarzy był podobny jak cmentarzy w innych miastach Europy. Najstarszym i przez długi czas jedynym cmentarzem katolickim na terenie miasta był ten położony wokół kościoła - Wniebowzięcia NMP na Górkach Plebańskich (Muznerowski 1922). Gdy na początku XIX wieku miasto zaczęło się rozrastać, cmentarz ów stał się zdecydowanie niewystarczający. Zamknięto go ostatecznie w 1819 roku, gdy udało się uruchomić nową, podmiejską, dwuwyznaniową nekropolię. Powstała ona przy drodze retkińskiej. Dzisiaj są to ulice Ogrodowa i Gdańska, w tamtym czasie teren położony był ok. $400 \mathrm{~m}$ od granic miasta. Okazało się jednak, że ta lokalizacja nie spełniała oczekiwań. Brak było ogrodzenia, między mogiłami wypasano krowy, co stało w sprzeczności z obowiązującym już od średniowiecza prawem kościelnym (Starczuk 2006). Mimo to nekropolię szybko powiększono (1833 r.), tak że rozciągała się do obecnej ulicy Zachodniej i Legionów. Problem z budową parkanu może wydawać się

${ }^{13}$ Dz.U., 2002, nr 162, poz. 1568.

${ }^{14}$ Dz.U., 1959, nr 11, poz. 62 z późn. zm. 
banalny, warto jednak zwrócić uwagę, że jest to istotna granica oddzielająca to, co święte od tego, co nieświęte. M. Różański (1995) tak opisuje zmagania łódzkich władz kościelnych o należyte traktowanie miejsca pochówków:

Po rozszerzeniu cmentarz katolicki był opasany z frontowej strony drewnianym płotem z bramą, z pozostałych zaś ogrodzony płotem z żerdzi, jako że parkan uległ zniszczeniu. Opornie jednak szło ogrodzenie tego cmentarza. [...] Dozór kościelny, chcąc zabezpieczyć teren cmentarza przed profanacją, postanowił go okopać i obsadzić drzewami. Budowniczy obwodu upomniał dozór, że okopanie cmentarza rowem i obsadzenie drzewami, chociaż jest o wiele tańsze niż postawienie parkanu, to jednak z uwagi na to, że cmentarz znajdował się na gruncie piaszczystym i na terenie niezabudowanym, to narażony będzie na wiejące z każdej strony wiatry. Nie będzie on miał żadnej trwałości i potrzebna będzie ciągła jego naprawa. Poza tym cmentarz leżał blisko traktu piotrkowskiego i okopany będzie stwarzał nieestetyczny widok. Zalecał więc, aby jak najszybciej przystąpiono do budowy parkanu wokół cmentarza (Różański 1995: 112).

Płot w końcu udało się wybudować, ale cmentarz był otwarty tylko do $1855 \mathrm{r}$. Wtedy wytyczono nowe miejsce grzebania zwłok - Cmentarz Stary przy Ogrodowej, który zaczął działać ${ }^{15} \mathrm{w} 1858$ roku. Zajmował on powierzchnię 4,7 ha i był przeznaczony nie tylko dla katolików, ale także protestantów i prawosławnych. W latach 80 . XIX wieku, poza granicami miasta, powstały również cmentarze na Zarzewie i na Chojnach (ul. Rzgowska). W 1896 roku zlokalizowano nekropolię we wsi Doły. Niecałe dwadzieścia lat później zdecydowano o budowie cmentarza na Mani (Przybysz 2007). W ciągu następnych kilkudziesięciu lat, wraz z rozwojem przestrzennym Łodzi, podmiejskie nekropolie zostały włączone w granice miasta.

Przełom XIX i XX wieku w Łodzi był także okresem lokowania cmentarzy innych wyznań. W 1892 roku powstał cmentarz żydowski (przy dzisiejszej ulicy Brackiej), w 1907 roku na Ogrodowej wydzielono część dla baptystów. W tym czasie założono cmentarz dla parafii ewangelicko-reformowanej na Starym Rokiciu. W 1945 roku w Łodzi funkcjonowało łącznie 37 nekropolii (Tabela 2).

Po II wojnie światowej w Łodzi nastąpiły zmiany. Część cmentarzy ewangelicko-augsburskich miasto zamieniło na cmentarze komunalne, tak jak w przypadku cmentarza na Dołach. Cmentarz przy ul. Rojnej 60 przekształcono w skwer, cmentarz przy ul. Wileńskiej $57 \mathrm{w}$ plac zabaw, a cmentarz przy ul. Skrzywanej 28 w park. Część cmentarzy przeszło pod zarząd parafii rzymskokatolickich, należały do nich cmentarz: ewangelicko-augsburski w Nowosolnej przejęty przez parafię rzymskokatolicką w Nowosolnej, cmentarz ewangelicko-augsburski w Radogoszczu dołączony do cmentarza rzymskokatolickiego na Radogoszczu. Przemianę przeszedł cmentarz ewangelicko-augsburski w Augustowie, na terenie którego zlokalizowano elektrociepłownię EC4 oraz cmentarz na Dąbrowie przekształcony w bocznicę kolejową. Reszta cmentarzy tego wyznania została porzucona i zapomniana.

${ }^{15}$ Można przesunąć jednak tę datę na 1854 r., wtedy to bowiem odbyły się tam pierwsze pochówki (Dominikowski 2004). 
Tabela 2. Łódzkie cmentarze w 1945 roku

\begin{tabular}{lcc}
\hline \multicolumn{1}{c}{ Organ administrujący } & Liczba & $\begin{array}{c}\text { Powierzchnia } \\
{[\mathrm{ha}]}\end{array}$ \\
\hline Kościół Ewangelicko- Augsburski & 19 & 39,43 \\
\hline Kościół rzymskokatolicki & 12 & 88,23 \\
\hline Polski Autokefaliczny Kościół Prawosławny & 2 & 2,64 \\
\hline Kościół Starokatolicki Mariawitów & 1 & 0,85 \\
\hline Kościół Ewangelicko-Reformowany & 1 & 0,32 \\
\hline Kościół Chrześcijan Baptystów & 1 & 1,86 \\
\hline Gmina Wyznaniowa Żydowska & 1 & 40,35 \\
\hline Ogółem & $\mathbf{3 7}$ & $\mathbf{1 7 3 , 6 8}$ \\
\hline
\end{tabular}

Źródło: A. Wiercińska (2012).

Do miasta dołączono: Rudę Pabianicką wraz z cmentarzem rzymskokatolickim przy ul. Mierzejowej 1 i ewangelicko-augsburskim przy ul. Sopockiej 18, Chojny z cmentarzem rzymskokatolickim św. Wojciecha przy ul. Kurczaki 81/85 i św. Franciszka przy ul. Rzgowskiej 156/158. Łódź zyskała także wiejskie cmentarze rzymskokatolickie w Łagiewnikach i na Retkinii oraz 10 ewangelickich cmentarzy w Augustowie, Olechowie, Janowie, Moskulikach, Grabieńcu, Antoniewie, Dąbrowie, Nowym Złotnie, Karolewie i Górkach Starych. W tym samym czasie w granicach miasta znalazł się również cmentarz rzymskokatolicki św. Anny na Zarzewie, do którego w 1975 roku przyłączono tereny, na których powstał cmentarz komunalny „Zarzew” przy ul. Przybyszewskiego 325. Rozrost miasta umożliwił powstanie dwóch nowych cmentarzy. W 1949 roku przy ul. Szczecińskiej 96/100 utworzono cmentarz rzymskokatolicki Matki Boskiej Nieustającej Pomocy, a w 1988 roku cmentarz komunalny „Szczecińska” przy ul. Hodowlanej 28/30.

W 1988 roku, po ostatnich zmianach granic, włączone zostały cmentarze: rzymskokatolicki w Nowosolnej i Mileszkach, ewangelicko-augsburski położony w Andrzejowie oraz inne nieczynne cmentarze tego wyznania: w Wiączyniu Górnym i w Łaskowicach. W 1992 roku powstał cmentarz rzymskokatolicki parafii p.w. Niepokalanego Poczęcia NMP w Andrzejowie, zaś w 2000 roku cmentarz rzymskokatolicki Wszystkich Świętych zlokalizowany przy ul. Zakładowej. Poza granicami administracyjnymi Łodzi znalazł się rzymskokatolicki cmentarz św. Maksymiliana Kolbego w Gadce Starej. (Tabela 3).

$\mathrm{Na}$ terenie Łodzi znajduje się 29 ogólnodostępnych nekropolii o łącznej powierzchni 207,45 ha, czyli $0,71 \%$ powierzchni miasta. Wszystkie tereny pocmentarne w Łodzi zajmują 12,9 ha co stanowi 0,04\% powierzchni miasta (Tabela 3, Ryc. 3). 
Tabela 3. Łódzkie cmentarze w 2011 roku pod względem powierzchni i organu administrującego

\begin{tabular}{lcc}
\hline \multicolumn{1}{c}{ Organ administrujący } & Liczba & $\begin{array}{c}\text { Powierzchnia } \\
{[\mathrm{ha}]}\end{array}$ \\
\hline Kościół rzymskokatolicki & 16 & 119,18 \\
\hline Gmina Wyznaniowa Żydowska & 1 & 39,22 \\
\hline Łódzki Zakład Usług Komunalnych & 3 & 29,78 \\
\hline Kościół Ewangelicko-Augsburski & 3 & 11,13 \\
\hline Polski Autokefaliczny Kościół Prawosławny & 2 & 2,64 \\
\hline Kościół Zielonoświątkowy & 1 & 2,47 \\
\hline Kościół Chrześcijan Baptystów & 1 & 1,86 \\
\hline Kościół Starokatolicki Mariawitów & 1 & 0,85 \\
\hline Kościół Ewangelicko-Reformowany & 1 & 0,32 \\
\hline Ogółem & $\mathbf{2 9}$ & $\mathbf{2 0 7 , 4 5}$ \\
\hline
\end{tabular}

Źródło: A. Wiercińska (2012).

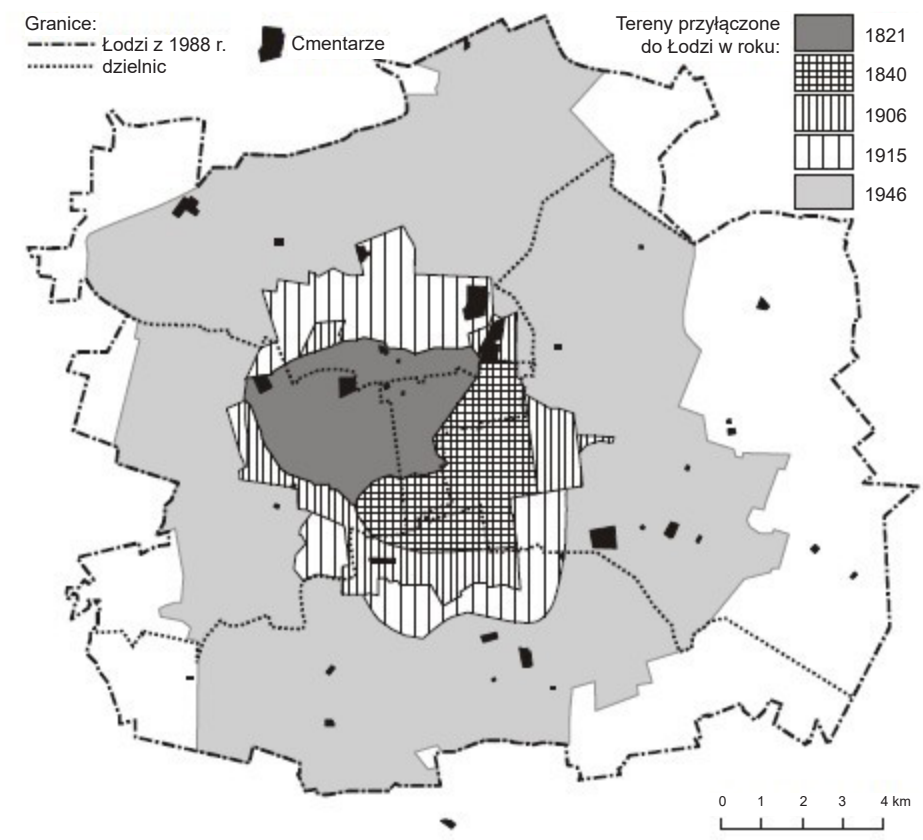

Ryc. 3. Cmentarze w przestrzeni miejskiej w Łodzi w 2012 roku Źródło: A. Wiercińska (2012: 16). 


\section{Zakończenie}

Problematyka lokalizacji cmentarzy może wydawać się marginalna w kontekście gospodarowania przestrzenią w miastach. Nie powinno tak jednak być. Nekropolie stanowiły i stanowić będą integralną część każdego krajobrazu kulturowego. Trudność i skomplikowanie lokalizacji i ich kształtu wynika z kilku czynników - przede wszystkim połączenia tego, co na wskroś przyziemne i pragmatyczne z tym, co wzniosłe i duchowe. Mamy więc z jednej strony wymagania sanitarne i strukturę demograficzną, a z drugiej strony religijność i tożsamość zarówno miejsca, jak i budowanej wokół niego wspólnoty. Cmentarze uczą historii. Gdy patrzymy na nagrobek na Starym Cmentarzu w Łodzi, na którym nazwisko najpierw pisane jest tak, że wiadomo, iż zmarły był niemieckojęzyczny, w kolejnym pokoleniu „spolszcza się” (np. „sch” przechodzi w „sz”) metafora palimpsestu staje się mniej metaforyczna.

Ewolucja podejścia do form i miejsc grzebania zmarłych pokazuje ewolucję szeroko rozumianej kultury. Widać tu jak świeckość przeplata się ze świętością. Widać także postęp nauki i wzrost świadomości dotyczącej elementarnych zasad higieny, ale także spadek lub wzrost znaczenia religii. Warto podkreślić również wielofunkcyjność cmentarzy. Dzisiaj niektóre nekropolie są atrakcjami turystycznymi (turystyka pamięci, turystyka sentymentalna) i miejscami wypoczynku. W Łodzi, w latach 2000. wyznaczono tzw. „Zielony Krąg Tradycji i Kultury”, w skład którego wchodzą Cmentarz Stary i Cmentarz Żydowski. Ma on m.in. wzbogacić ofertę turystyczną miasta. Jest to jednocześnie obszar ważny środowiskowo - poprawa jakości powietrza, ochrona przed hałasem, zapobieganie miejskiej wyspie ciepła.

\section{Bibliografia}

Ariès Ph., 1989, Człowiek i śmierć, Państwowy Instytut Wydawniczy, Warszawa.

Długozima A., 2011, Cmentarze jako ogrody żwych i umarlych, Doktoraty Katedry Sztuki Krajobrazu SGGW, Warszawa.

Dominikowski J., 2004, Nekropolia Łodzi wielkoprzemysłowej. Cmentarz Stary przy ulicy Ogrodowej. Dzieje i sztuka 1854-1945, Wydawnictwo Konserwatorów Dzieł Sztuki, Łódź.

Dziobek-Romański J., 1998, Cmentarze-zarys regulacji historycznych, prawnych i kanonicznych, „Rocznik Historyczno-Archiwalny”.

Górniak M., 2003, Nekropolie. Religia. Encyklopedia, Wydawnictwo Naukowe PWN, Warszawa.

Holly G., 2007, Stan zachowania zabytkowych cmentarzy chrześcijańskich na terenie Bieszczadzkiego Parku Narodowego, „Roczniki Bieszczadzkie”, 15.

Kalinowski A., 2001, Cmentarze: ewolucja przepisów w kościelnym ustawodawstwie kodeksowym XX w., Wydawnictwo Bernardinum, Pelpin. 
Klima E., 2011, Przestrzeń religijna miasta, Wydawnictwo Uniwersytetu Łódzkiego, Łódź. Kolbuszewski J., 1996, Cmentarze, Wydawnictwo Dolnośląskie, Wrocław.

Loudon J.C., 1843, On the laying out, planting and managing of cemeteries and on the improvement of churchyards, https://books.google.pl/books/about/On_the_Laying_ Out_Planting_and_Managing.html?id=OOcCAAAAYAAJ\&redir_esc $=\mathrm{y}$

Muznerowski S., 1922, Przyczynki do monografii Łodzi, Łódź.

Przybysz M., 2007, Kościół rzymskokatolicki w Łodzi w latach 1945-1956, Wydawnictwo Ibidem, Łódź.

Różański M., 1995, Dzieje najstarszych łódzkich cmentarzy katolickich do końca XIX wie$k u$, ,Łódzkie Studia Teologiczne”, 4.

Sobczak A., 2003, Poradnik cmentarny: kościelne i cywilne normy prawne o cmentarzach i chowaniu zmarlych wraz z orzecznictwem, Gaudentinum, Gniezno.

Sobczak J., Gołda-Sobczak M., 2018, Prawo do grobu jako problem kulturowy i prawny, „Zeszyty Naukowe Katolickiego Uniwersytetu Lubelskiego”, 60, 1(241).

Starczuk J., 2006, Cmentarz i stół. Pogranicze prawosławno-katolickie w Polsce i na Biatorusi, Wydawnictwo Uniwersytetu Wrocławskiego, Wrocław.

Tanaś S., 2008, Przestrzeń turystyczna cmentarzy. Wstęp do tanatoturystyki, Wydawnictwo Uniwersytetu Łódzkiego, Łódź.

Wiercińska A., 2012, Cmentarze łódzkie na tle rozwoju ludnościowego i przestrzennego miasta, „Studia z Geografii Politycznej i Historycznej”, 1: 207-220.

\section{Akty prawne}

Rozporzadzenie Ministra Gospodarki Komunalnej z dnia 25 sierpnia 1959 roku w sprawie określenia, jakie tereny pod względem sanitarnym sa odpowiednie na cmentarze (Dz.U., 1995, nr 52, poz. 315 z późn. zm.).

Rozporzadzenie Ministra Infrastruktury z dnia 7 marca 2008 roku w sprawie wymagań, jakie musza spetniać cmentarze, groby i inne miejsca pochówku zwłok i szczątków (Dz.U., 2008, nr 48, poz. 284).

Ustawa z dnia 28 marca 1933 roku o grobach i cmentarzach wojennych (Dz.U., nr 39, poz. 311).

Ustawa z dnia 31 stycznia 1959 roku o cmentarzach i chowaniu zmarlych (Dz.U., 1959, nr 11, poz. 62 z późn. zm.).

Ustawa z dnia 23 lipca 2003 roku o ochronie zabytków i opiece nad zabytkami (Dz.U., 2002, nr 162, poz. 1568).

\section{A CEMETERY IN THE SPATIAL STRUCTURE OF THE CITIES}

Abstract: Dying is not part of the contemporary global pop culture that glorifies youth and vitality. If one considers the Catholic sacrum-taboo of death additionally, it turns out that there is no place for cemeteries today. The aim of the article is to show that cemeteries cannot be denied. They are part of every civilization and are baded in space and landscape. An important observation is that the meaning and location of the cemeteries has changed, as has the culture. The example of Lodz was used.

Keywords: cemeteries, location of cemeteries, Lodz, Lodz cemeteries. 
Dr hab. Ewa Klima, prof. PŁ Politechnika Łódzka Wydział Budownictwa, Architektury i Inżynierii Środowiska Instytut Inżynierii Środowiska i Instalacji Budowlanych Kolegium Gospodarki Przestrzennej e-mail: ewa.klima@p.lodz.pl

Dr inż. Barbara Wycichowska Politechnika Łódzka

Wydział Budownictwa, Architektury i Inżynierii Środowiska Instytut Architektury i Urbanistyki e-mail: barbara.wycichowska@p.lodz.pl

Weronika Popek Niezależny badacz e-mail: weronipopek@gmail.com 